e-ISSN: 2550-1313 | p-ISSN: 2087-9849

http://jurnal.fkip.unila.ac.id/index.php/jpp/

\title{
Students' Satisfaction on School Services in a State College in the Philippines
}

\author{
Mark Erana Patalinghugi", Joan Hortilano' ${ }^{1}$, Ernil Repaso ${ }^{1}$, Angel Mollona ${ }^{1}$, \\ Haidee Fuentes Patalinghug ${ }^{2}$ \\ 'Department of Criminology, J.H. Cerilles State College- Dumingag Campus, Philippines \\ ${ }^{2}$ School of Teacher Education, J.H. Cerilles State College-Dumingag Campus, Philippines \\ *Corresponding email: mark.patalinghung@jhcsc.edu.ph
}

Received: 29 March $2020 \quad$ Accepted: 24 June $2020 \quad$ Published: 21 August 2020

Abstract: Students' Satisfaction on School Services in a State College in the Philippines. Objective: This study was purposely conducted to determine the satisfaction level of Bachelor of Science in Criminology students on the school services offered in J.H. Cerilles State College (JHCSC), Philippines in 2019. Methods: This is a descriptive type of research utilizing a modified-validated questionnaire from the working guide of the accreditors in the Accrediting Agency of Chartered Colleges and Universities in the Philippines, Inc. (AACCUP). Frequency Counts, Percentage, and Weighted Average Mean were used in analyzing the data. Total enumeration was used as the sampling methodology. A total of 152 criminology students were identified as the respondents of the study. Findings: Results show that library and guidance services have the highest level of satisfaction rating while school canteen and criminology laboratory have the lowest students' satisfaction. Conclusion: The students were satisfied with the services offered by those offices that directly attended to their academic and emotional needs.

Keywords: students satisfaction, school services, services quality, higher education institution.

Abstrak: Kepuasan Mahasiswa terhadap Layanan Sekolah di Perguruan Tinggi Negeri di Filipina.

Tujuan: Penelitian ini dilakukan untuk mengetahui tingkat kepuasan mahasiswa S1 Kriminologi terhadap layanan sekolah yang ditawarkan di J.H. Cerilles State College (JHCSC), Filipina pada tahun 2019. Metode: Penelitian ini merupakan penelitian deskriptif dengan menggunakan kuesioner yang telah dimodifikasi-validasi dari pedoman kerja para akreditor di Accrediting Agency of Chartered Colleges and Universities in the Philippines, Inc. (AACCUP). Frekuensi Hitung, Persentase, dan Rata-rata Tertimbang digunakan dalam menganalisis data. Metode pencacahan total digunakan sebagai metode pengambilan sampel. Sebanyak 152 mahasiswa jurusan kriminologi diidentifikasi sebagai responden penelitian. Temuan: Hasil penelitian menunjukkan bahwa layanan perpustakaan dan bimbingan memiliki tingkat kepuasan tertinggi sedangkan kantin sekolah dan laboratorium kriminologi memiliki kepuasan siswa terendah. Kesimpulan: Para siswa puas dengan layanan yang ditawarkan oleh kantor-kantor yang secara langsung memenuhi kebutuhan akademik dan emosional mereka.

Kata kunci: kepuasan mahasiswa, pelayanan sekolah, kualitas layanan, institusi pendidikan tinggi.

\section{To cite this article:}

Patalinghung, M, E., Hortilano, J, E., Repaso, E, J., Mollona, A, A., \& Patalinghung, H, F. (2021). Students' Satisfaction on School Services in a State College in the Philippines. Jurnal Pendidikan Progresif, 11(1), 165-175. doi: 10.23960/jpp.v11.i2.202103. 


\section{INTRODUCTION}

Higher Education Institutions (HEIs) is a tertiary level of education recognized as one of the most critical tools in fostering a nation's economic growth and development (Mukhtar, Anwar, Ahmed, \& Baloch, 2015). Higher education is increasingly viewed as a service sector, emphasizing the significance of meeting clients' needs and expectations in order to attain the intended position and share of the student market (Sarsale \& Caday, 2020). Ensuring excellent service delivery to increase efficiency, loyalty, students' retention, and a conducive learning environment is a challenge to achieve a competitive advantage over other institutions (Schertzer \& Schertzer, 2004). The situation in higher education is evolving because of globalization resulting in increased commercial importance (Butt \& Rehman, 2010; Khosravi, Poushaneh, Roozegar, \& Sohrabifard, 2013). Factors that make it possible for education institutions to attract and keep learners should be taken carefully in today's competitive educational setting when learners have many options. There is no doubt academic scholars (e.g. Abdullah 2006; Gruber et al. 2010; Hasan et al. 2008; Santini et al. 2017; Weerasinghe and Fernando 2018) conducted studies to measure the clients' satisfaction to fully recognize their fundamental context and eventually create advanced methodologies and build clients' patronage in HEIs.

Customers of HEIs include employees, the public sector, industry, the community, employers, and students (Guilbault 2018; Kanji, Malek, and Tambi 1999; Pereira and Silva 2003). With diversity of clients among HEIs, the quest for proper service delivery to satisfy customers, draws attention among institutions, and no one is exempted. Among HEIs, students are the main customers and have more control and knowledge in the selection and knowing the standard of services as users, making them more responsive and selective. This implies that students are the ones who define what is the quality and satisfaction in HEIs (Onditi \& Wechuli, 2017). Thus, HEIs must consider and meet students' demands and needs (Temizer \& Turkyilmaz, 2012).

For the institution to thrive, it is dependent on the students' satisfaction, HEIs must discover their areas of strength and areas to be improved. Hameed and Amjad (2011) explicitly suggest that student satisfaction is not only a matter of evaluation, but a detailed evaluation should be carried to find out all the variables that lead to student satisfaction.

Students' satisfaction is a big concern for HEIs (A1-Sheeb, Hamouda, \& Abdella, 2018; Temizer \& Turkyilmaz, 2012), as it is the major indicator of school and student's performance (Bryant \& Bodfish, 2014), and effective and innovative strategies for attracting, retaining, and strengthening connections with students. HEI's need to examine their services for future improvements on a regular basis, as they acknowledge the importance of service quality in higher education (Kontic, 2014).

Students' satisfaction have varied definition which depends on the what subject matter it represents (Al-Sheeb et al., 2018; Annamdevula \& Bellamkonda, 2016). However, the most recognizable and acceptable definition which pertains to students educational experience (Elliott \& Healy, 2001). Students' satisfaction can be categorized into classroom teaching and learning experience, and the comprehensive students experience (Aldridge \& Rowley, 1998).

Scholars conclude that institutional factors such as quality of the institution in giving feedback, and clear expectation (Appleton-Knapp \& Krentler, 2006), development and growth of students, student centered services and campus relations (Thompson, 2014), and feedback quality, learning materials and library facilities (García-Aracil, 2009; Kuh \& Hu, 2001; Sojkin, 
Bartkowiak, \& Skuza, 2012; Weerasinghe \& Fernando, 2018) influence how students' views satisfaction to school services. Additionally, academic and non-academic aspects, as well as accessibility, prestige, and program challenges, are significant determinants of student satisfaction (Ali, Zhou, Hussain, Nair Kumar, \& Ragavan, 2016; Sojkin et al., 2012).

Numerous academics examine service quality in the educational institutions due to its significance and effects. The increasing trends of service quality among HEIs recently do not exempt the Philippine higher education. To address these challenges, the Commission on Higher Education (CHED) issued circulars to improve the service quality in HEIs. In section 3 of CMO 21 series of 2006 and Section 10 of CMO 09 series of 2013 mandated the Higher Education Institutions (HEIs) in the Philippines to provide students-oriented programs and services to upkeep with academic instruction envisioned for holistic human development for active engagement in country-building (CHED, 2006). The same CMOs stipulate the important student welfare programs and services needed to promote students' well-being. HEIs are also required to ensure an adequate number of student service personnel to serve the students population. As a result, it is expected that colleges and universities continue to undertake regular assessments on students' expectations and impressions as part of their quality improvement efforts (Awang \& Ismail, 2010).

Meanwhile, JHCSC is one of the Philippines' HEIs that provide services to students and deliver quality education. It is a government funded institution delivering free education among its students. It offers CHED recognized programs and accredited as State College and University (SUC) Level II. Martirosyan (2015) suggested much importance should be placed on evaluating the services and programs offered by government institutions and determining their students' expectations. Moreover, the government and the stakeholders give its commitment for the promotion of conducive learning environment and opportunities for students (Butt \& Rehman, 2010). This prompted the researchers to evaluate the students' satisfaction to school service in the institution and know the possible methodology to improve the college's services. This study is significant since it assesses the quality of services as well as student satisfaction to keep up with market-driven and costumer-centered educational setting. The study was meant to determine the level of satisfaction of the Bachelor of Science in Criminology (BSCrim) students on the school services offered in JHCSC-DumingagCampus. Specifically, the study aimed to:

1. Determine the levels of satisfaction of the students in the school services offered; and

2. Provide a suggestive mechanism to improve the school services offered to students.

\section{Conceptual Framework}

According to Sario (2015), as students developed and benefitted from the institution's programs and services, it is vital to evaluate the program offerings, the workforce, and overall services to know why they enrolled in the College/ University. Feedback is required to encourage the institution to make improvements for the increased likelihood of students' success.

The issue in measuring quality in higher education is complex. In doing so, HEIs have a variety of techniques to choose from. The main concern is to select the most appropriate method to implement with consideration on cost and procedures (Kontic, 2014). Likewise, non-profit government education institution faced difficulty to adopt an enterprise-driven service quality model to assess students' satisfaction the way it is (Waugh, 2002). This is due to the quality of 
services colleges offer sets them apart from their private equivalents (Sharma, Kaur, \& Kaur, 2018)

In this study Brady and Cronin's (2001) hierarchical service quality model was the appropriate model for comprehensive and multilevel approaches in explaining service quality. This consists of primary elements such as interaction quality, physical environment quality, and the outcome quality having three sub-dimensions. In addition, clients apply their appraisals of the subdimensions to shape their expectations of an entity's success in each of the three primary dimensions. Such expectations contribute significantly to understanding the quality of services. This implies the client's views were funded through assessment of performance at several stages, combining them to create a general view of service quality.

The service product bundle model of Douglas, Douglas, and Barnes (2006) was also used in this study. Subsequently, in HEIs, three elements are part of service delivery: physical or facilitating goods, explicit service, and psychological service. In this model, variables such as student support facilities, staff helpfulness, and business procedures are considered elements in students' satisfaction assessment procedure which aid in the formulation of the mechanism to improve the students' services.

\section{METHODS}

The study used a descriptive research method to discover the level of students' satisfaction towards the school's quality services. The participants of the study were 152 Bachelor of Science in Criminology (BSCrim) students which comprises $242^{\text {nd }}$ year students, $623^{\text {rd }}$ year student and $664^{\text {th }}$ BSCrim students of J.H. Cerilles State College Duminga Campus, Zamboanga del Sur, Philippines during the second semester of S.Y. 2018-2019. The participating student aged 18 years old and above, 99 were male and 53 were female and mostly stayed in the institution for 3 years and above. Because there were fewer students, total enumeration was employed.

A modified questionnaire patterned from the working guide of the accreditors in AACCUP was used. A survey instrument was taken from Areas 4 (Students Support), 7 (Library), 8 (Physical Facilities), and 9 (Laboratories) which was validated by two (2) AACCUP local accreditors of the college and found to be valid for the present study. The selection of areas included in the survey were identified based on Sojkin et al. (2012) and Ali et al. (2016) to include offices which offered services to students that may directly or indirectly affect students' satisfaction such as social conditions, campus climate, educational facilities, and college practices. Revision was made based on the suggestions of the accreditors. For the reliability construct of the instrument pilot testing was done which yielded results that were acceptable with an alpha within the range of $0.70-0.77$ and found that alpha values relatively high based on Taber (2018) that was fit for use. The survey questionnaire consists of three parts. Part I contained the school's level of satisfaction school services, such as criminalistics laboratory, school canteen, guidance office, student affairs office, school library, clinic, registrar office, school administration, journal/publication office, computer laboratory, accounting office. Part II focused on the suggested mechanisms to improve the school services offered to students.

As an ethical aspect for the study, data collection began with the researchers obtaining clearance from research committee and school officials to conduct the study following the principles mentioned in Stang (2015) with considering social value, scientific validity, favorable risk-benefit ratio, participants selection, 
independent review, and informed consent of the participants. The data gathering was done in the month of January 2019.

During the data gathering, researchers personally administered the survey questionnaire to the participants. The researchers explained to the participants the aim and scope of the study and ensuring that their responses and identity will be taken with utmost confidentiality. After the participants completed the survey, their responses were numbered according to the sequence of distribution and tallied for data analysis.

In measuring the responses of students, Three-Points Likert Scale was used. The scoring procedure was based on construct successive interval, and equal interval scales (Braunsberger $\&$ Gates, 2009) of 2 and 1.49 for each scale points for meaningful statistical analyses and interpretation. It was utilized to interpret the level of satisfaction on the school services offered, as presented in table 1.

Table 1. Three-points likert scale for students' level of satisfaction on school services

\begin{tabular}{ccc}
\hline Scale & $\begin{array}{c}\text { Interval } \\
\text { Scale }\end{array}$ & Description \\
\hline $\mathbf{5}$ & $3.50-5.00$ & Very Satisfied \\
\hline $\mathbf{3}$ & $2.50-3.49$ & Satisfied \\
\hline $\mathbf{1}$ & $1.00-2.49$ & Not Satisfied \\
\hline
\end{tabular}

In gathering suggested solutions to improve the offered school services Three-Points Likert Scale was used with construct successive interval and equal interval scales (Braunsberger \& Gates, 2009), as seen in table 2.

Table 2. Three-points likert cale for the suggested mechanism to improve the school services offered

\begin{tabular}{ccc}
\hline Scale & $\begin{array}{c}\text { Interval } \\
\text { Scale }\end{array}$ & Description \\
\hline $\mathbf{5}$ & $4.50-5.00$ & Highly Suggested \\
\hline $\mathbf{3}$ & $2.50-3.49$ & Suggested \\
\hline $\mathbf{1}$ & $1.00-1.49$ & Not Suggested \\
\hline
\end{tabular}

The data acquired were analyzed using frequency counts, percentage, and weighted average mean.

\section{RESULTS AND DISCUSSION}

The result of descriptive analysis on satisfaction of BSCrim students on the school services are as follows;

Table 3. Level of satisfaction on school services offered to students

\begin{tabular}{|c|c|c|}
\hline School Services & WAM & Description \\
\hline $\begin{array}{l}\text { 1. Criminology } \\
\text { Laboratory }\end{array}$ & 2.79 & Satisfied \\
\hline 2. School Canteen & 2.90 & Satisfied \\
\hline $\begin{array}{l}\text { 3. Guidance } \\
\text { Service }\end{array}$ & 4.01 & Very Satisfied \\
\hline 4. Students Affairs & 3.84 & Very Satisfied \\
\hline 5. School Library & 4.05 & Very Satisfied \\
\hline 6. School Clinic & 3.69 & Very Satisfied \\
\hline 7. Registrar & 3.64 & Very Satisfied \\
\hline $\begin{array}{l}\text { 8. Journal/Publicat } \\
\text { ion Office }\end{array}$ & 3.59 & Satisfied \\
\hline $\begin{array}{l}\text { 9. Computer } \\
\text { Laboratory }\end{array}$ & 2.92 & Satisfied \\
\hline 10. Accounting & 3.44 & Satisfied \\
\hline Overall Mean & 3.49 & Satisfied \\
\hline
\end{tabular}

Table 3. present the result of descriptive analysis of the students' level of satisfaction on school services. There are ten areas presented in this survey. The table shows that students were very satisfied with the offices they constantly access. Library, for example, gained the highest satisfaction rating from the students. Studies assessing the level of satisfaction of student on the library services have been done ( e.g. Atique \& Siddiqui, 2019; Madusanka, Nawarathne, \& Rathnayaka, 2019; Magulod, 2017; Mohindra \& Kumar, 2015; Nawarathne \& Singh, 2013). Those studies revealed that the influential factor which affects the student's satisfaction on services arose from the helpfulness of staff and userfriendly environment. Students have also identified that the student support services such as Guidance Service, Students Affairs, School Clinic, and 
Registrar were very satisfactory. These offices are the ones that students frequently visited and accommodated students' concerns in their stay in the college and identified by Arangote (2018) as necessary and part of the student's life. These support services was recognized as vital and students first gained institutional experiences and satisfaction to students support services fulfill students' expectation and also invites new students (Silva \& Fernandes, 2012). Furthermore, studies on guidance services reflected the similarity with this finding. Students in public schools in the Philippines were very satisfied with the Guidance services and showed exceptional services to students (Arangote, 2018; Magulod, 2017).

Students were satisfied with other services they received; however, the two identified areas, Criminology Laboratory and School Canteen were the lowest rated in terms of satisfaction. The reason why the students have rated these areas the lowest due to practical reasons. In the laboratory setting, students have encountered difficulty to manipulate and utilized laboratory facilities. This experience would lead to lower satisfaction level among students. The study of Maristela and colleagues (2015) also found the learning experience in the usage and operation of laboratory facilities became a problem among students and affecting their satisfaction. Laboratory facilities which did not addresses the learning needs of the student can be the factor that lead to students' dissatisfaction (Sukhdeep Kaur, 2016).

For the School Canteen, students showed lower satisfaction and the underperforming area along with the Criminology Laboratory. Studies shows that the canteen was poorly rated by the students because of food services, and under performance (Sarsale \& Caday, 2020) and Awang and Ismail (2010) identified service improvement on this area in the university and colleges.

Generally, the result in table 3 shows that the school services offered by the college met the students' expectation and thus making them feel satisfied while other areas with excellent services exceeds their expectation and results to a very satisfying experience while availing the services. The most common areas were identified to be the contributor to overall students' satisfactions of the services in HEIs such as the comfortable school environment, public areas, access to campus, the laboratory, and educational services (Kärnä \& Julin, 2015).

Table 4. depict the suggested mechanism for the areas having the rating of satisfied and maintain the areas with the rating of very satisfied. There were ten areas discussed in the survey questionnaires. The descriptive analysis result shows that all the mechanism to improve the school services offered for students were highly suggested.

The most notable suggested mechanism to improve the school services was to allocate an additional budget for enhancing necessary facilities for better quality health services. This result can be linked to the result of the laboratory satisfaction rating. Student perceived that health services need budget allocation for improvement due to the nature of the course, which include laboratory and other practical activities that needs the support from the health service unit of the institution. This result was in consonance with the study of Maristela et al. (2015) which revealed the need for provision of first aid equipment and other related facilities, especially if accidents will occur during laboratory activities.

The findings shows that development of electronic systems to hasten the services was the highly suggested mechanism for improving the school services. Additionally, connectivity 
Table 4. Suggested mechanisms to improve the school services offered to the students

\begin{tabular}{|c|c|c|}
\hline Suggested Mechanisms & WAM & Description \\
\hline $\begin{array}{l}\text { 1. Hire additional staff for } \\
\text { the improved service } \\
\text { delivery. }\end{array}$ & 4.13 & $\begin{array}{c}\text { Highly } \\
\text { Suggested }\end{array}$ \\
\hline $\begin{array}{l}\text { 2. Develop a system to } \\
\text { hasten the purchase of } \\
\text { supplies and equipment. }\end{array}$ & 4.12 & $\begin{array}{c}\text { Highly } \\
\text { Suggested }\end{array}$ \\
\hline $\begin{array}{l}\text { 3. Purchase additional library } \\
\text { holding to equate a } \\
\text { number of books to } \\
\text { students. }\end{array}$ & 4.16 & $\begin{array}{c}\text { Highly } \\
\text { Suggested }\end{array}$ \\
\hline $\begin{array}{l}\text { 4. Allocate additional } \\
\text { budget for the laboratory } \\
\text { facilities and equipment. }\end{array}$ & 4.18 & $\begin{array}{c}\text { Highly } \\
\text { Suggested }\end{array}$ \\
\hline $\begin{array}{l}\text { 5. Develop an electronic } \\
\text { system to provide fast and } \\
\text { efficient service to } \\
\text { students mainly during } \\
\text { enrolment } \\
\text { examination. }\end{array}$ & 4.28 & $\begin{array}{c}\text { Highly } \\
\text { Suggested }\end{array}$ \\
\hline $\begin{array}{l}\text { 6. Enhance the internet } \\
\text { facilities and install } \\
\text { additional router for a } \\
\text { faster connectivity. }\end{array}$ & 4.25 & $\begin{array}{c}\text { Highly } \\
\text { Suggested }\end{array}$ \\
\hline $\begin{array}{l}\text { 7. Establish a local area } \\
\text { network system for faster } \\
\text { sharing of files and record } \\
\text { checking. }\end{array}$ & 4.24 & $\begin{array}{c}\text { Highly } \\
\text { Suggested }\end{array}$ \\
\hline $\begin{array}{l}\text { 8. Employ staff to manage } \\
\text { the school canteen. }\end{array}$ & 4.14 & $\begin{array}{c}\text { Highly } \\
\text { Suggested }\end{array}$ \\
\hline $\begin{array}{l}\text { 9. Set a schedule and } \\
\text { convenient time for the } \\
\text { student's consultation and } \\
\text { counseling. }\end{array}$ & 4.25 & $\begin{array}{c}\text { Highly } \\
\text { Suggested }\end{array}$ \\
\hline $\begin{array}{l}\text { 10. Allocate an additional } \\
\text { budget for enhancing } \\
\text { necessary facilities for } \\
\text { better quality health } \\
\text { services. }\end{array}$ & 4.32 & $\begin{array}{c}\text { Highly } \\
\text { Suggested }\end{array}$ \\
\hline Overall Mean & 4.27 & $\begin{array}{c}\text { Highly } \\
\text { Suggested }\end{array}$ \\
\hline
\end{tabular}

is an essential tool for the learning environment it was also one of the highly suggested mechanisms to improve the school services. This implies HEIs need automation and fast service delivery during enrollment and examination as students during this period secured clearances to offices which handles students' concerns. Enhanced connectivity and local area network system was also perceived to be the facilitating factor to ensure the quality of students' services in the campus and viewed to be essential in improving the overall students' satisfaction experiences. This result is in consonance with previous studies which viewed that those facilities that will increase productivity of students should be prioritized such as the internet, the local area network and delivery of e-resources (Madusanka et al., 2019). For example, the traditional enrollment procedure meeting students' one-on-one was replaced by a web-based enrollment system which can be self-reliant and fast transaction (Hornak, Akweks, \& Jeffs, 2010). This meant long queues or prior preparations to avail of such services. With the advances in technology, offering services will become more convenient in student-centered services if future technology tools are employed. However, another study, opposed the result from this mechanism which suggest that integration of technology in school transaction during enrollment consumes students' time and posed difficulty during advising questions that leads to negative perception of the institution (Lightfoot, 2014). Nevertheless, students viewed information and technology facilities as important aspect of students' learning experience (Douglas et al., 2006). All the factors mentioned were considered to be the resources of organization and can improve and maximize service quality (Silva \& Fernandes, 2012).

On the other side, developing a system to hasten the purchase of supplies and equipment scores lowest among suggested mechanisms. This further suggests that students are more concerned about the services received to them than materials, supplies, and physical facilities in the office.

Additional assertion in the suggested 
mechanism to improve the school services by hiring additional staff to improve service delivery was also given importance among the students. This finding was also considered in a study conducted in leading Philippine state universities in Eastern Visayas. The authors recommend for the additional staff to improve responsiveness and timeliness of giving feedback especially during peak periods (Sarsale \& Caday, 2020).

\section{CONCLUSIONS}

The current study provides clear evidence on the type of services in which the students were highly satisfied. The students were satisfied with the services offered by those offices that directly attended to their academic and emotional needs. School services that often accessed by the students gains higher recognition, and more likely leads to a very satisfactory experience. While areas that have inadequate facilities for service delivery scored lower ratings. Personalized attention to each student such as providing helping hand, user-friendly environment, availability of resources and responsiveness can be a mechanism to attain students' satisfaction. Among the services offered the library followed by the guidance service received the highest ratings.

Moreover, the institution must adopt technology-driven processes to cater to their clients' changing needs, as students gave greater importance to fast service delivery. The application of technology and automation in catering to students' issues and concerns was suggested for the school to address students' changing needs. Students were not concerned primarily about the materials and facilities, but rather on the actual services they received based on personalized experiences. The purpose is to meet students' needs; their suggestions to improve service delivery directly impact the institution's business procedures and student satisfaction. Overall, students have pointed out existing areas on the services of the institution which can be improve.

\section{- REFERENCES}

Abdullah, F. (2006). Measuring service quality in higher education: HEdPERF versus SERVPERF. Marketing Intelligence and Planning, 24(1), 31-47. Retrieved from Al-Sheeb, B., Hamouda, A. M., \& Abdella, G. M. (2018). Investigating Determinants of Student Satisfaction in the First Year of College in a Public University in the State of Qatar. Education Research International.

Aldridge, S., \& Rowley, J. (1998). Measuring customer satisfaction in higher education. Quality Assurance in Education, 6(4), 197-204.

Ali, F., Zhou, Y., Hussain, K., Nair Kumar, P., \& Ragavan, N. A. (2016). Does higher education service quality affect student satisfaction, image and loyalty? A study of international students in Malaysian public universities Introduction. Quality Assurance in Education, 24(1).

Annamdevula, S., \& Bellamkonda, R. S. (2016). The effects of service quality on student loyalty: the mediating role of student satisfaction. Journal of Modelling in Management, 11(2), 446462.

Appleton-Knapp, S. L., \& Krentler, K. A. (2006). Measuring student expectations and their effects on satisfaction: The importance of managing student expectations. Journal of Marketing Education, 28(3), 254-264.

Arangote, E. M. (2018). Assessment of Student Services in a State University for Policy Recommendations. The Normal Lights, 
12(2), 145-167.

Atique, M., \& Siddiqui, I. A. (2019). Evaluation of Users Satisfaction with Library Resources and Services at AlKabir Polytechnic, Jamshedpur: A Case Study. Journal of Library \& Information Science, 9(3), 201-207.

Awang, H., \& Ismail, N. A. (2010). Undergraduate Education/ : A Gap Analysis Of Students' Expectations and Satisfaction. Problems of Education in the 21st Century, 21(2005), 1-8.

Brady, M. K., \& Joseph Cronin. J. (2001). Some New Thoughts on Conceptualizing Perceived Service Quality: A Hierarchical Approach. Journal of Marketing, 65(3), 34-49.

Braunsberger, K., \& Gates, R. (2009). Developing inventories for satisfaction and Likert scales in a service environment. Journal of Services Marketing, 23(4), 219-225.

Bryant, J., \& Bodfish, S. (2014). The Relationship of Student Satisfaction to Key Indicators for Colleges and Universities. Coralville, IA: NoelLevitz

Butt, B. Z., \& Rehman, K. U. (2010). A study examining the students satisfaction in higher education. In Procedia - Social and Behavioral Sciences (Vol. 2, pp. 5446-5450). Elsevier Ltd.

CHED (2006) Guidelines on Student Affairs and Service Program, Pub. L. No. 21.

Douglas, J., Douglas, A., \& Barnes, B. (2006). Measuring student satisfaction at a UK university. Quality Assurance in Education, 14(3), 251-267.

Elliott, K. M., \& Healy, M. A. (2001). Journal of Marketing for Higher Education The Expected Monetary Value of a Student/ : A Model and Example The Expected
Monetary Value of a Student/ : A Model and Example. Journal of Marketing for Higher Education, 10(4), 1-11.

García-Aracil, A. (2009). European graduates' level of satisfaction with higher education. Higher Education, 57(1), 121.

Gruber, T., Fuß, S., Voss, R., \& Gläser Zikuda, M. (2010). Examining student satisfaction with higher education services: Using a new measurement tool. International Journal of Public Sector Management, 23(2), 105-123.

Guilbault, M. (2018). Students as customers in higher education: The (controversial) debate needs to end. Journal of Retailing and Consumer Services, 40(April 2017), 295-298.

Hameed, A., \& Amjad, S. (2011). Students' Satisfaction in Higher Learning Institutions: A Case Study of COMSATS Abbottabad, Pakistan. IRANIAN JOURNAL OF MANAGEMENT STUDIES, 4(1), 63-77.

Hasan, H. F. A., Ilias, A., Rahman, R. A., \& Razak, M. Z. A. (2008). Service Quality and Student Satisfaction: A Case Study at Private Higher Education Institutions. International Business Research, 1(3).

Hornak, A. M., Akweks, K., \& Jeffs, M. (2010). Ethics in an Online Environment. New Directions for Community Colleges, 150(8), 79-87.

Kanji, G. K., Malek, A., \& Tambi, B. A. (1999). Total Quality Management in Teacher Education Institutions. Total Quality Management, 10(1), 129-153.

Kärnä, S., \& Julin, P. (2015). A framework for measuring student and staff satisfaction with university campus facilities. Quality Assurance in Education, 23(1), 47-66. 
Khosravi, A. A., Poushaneh, K., Roozegar, A., \& Sohrabifard, N. (2013). Determination of Factors Affecting Student Satisfaction of Islamic Azad University. Procedia Social and Behavioral Sciences, 84, 579-583.

Kontic, L. (2014). Measuring service quality in higher education: THE CASE OF SERBIA. International Conference MakeLearn 2014: Human Capital without Borders: Knowledge and Learning for Quality of Life, 645-654.

Kuh, G. D., \& Hu, S. (2001). The effects of student-faculty interaction in the 1990s. Review of Higher Education, 24(3), 309-332.

Lightfoot, J. M. (2014). A Web-Based Knowledge Management Tool Utilizing Concept Maps for On-Line Student Advising. Journal of International Technology \& Information Management, 23(1), 41-56.

Madusanka, W. V. D., Nawarathne, I. M., \& Rathnayaka, R. M. K. T. (2019). Analyzing user Satisfaction with Academic Library Services using CRISP-DM Process. SRELS Journal of Information Management, 56(3), 135139.

Magulod, G. C. (2017). Extent of Attainment of the Intended Program Attributes, Retrospection and Satisfaction of BS Industrial Technology Graduating Students from One Campus of a State University in Region 2 , Philippines. Asia Pacific Journal of Multidisciplinary Research, 5(4), 107-117.

Maristela, J., Moredo, D., Panaligan, L., Pontalba, F., Sabater, P. A., \& Caiga, B. T. (2015). Satisfaction of Maritime Students in using Laboratory Facilities. Asia Pacific Journal of Maritime
Education, 1(1), 33-39.

Martirosyan, N. (2015). An examination of factors contributing to student satisfaction in Armenian higher education. International Journal of Educational Management, 29(2), 177-191.

Mohindra, R., \& Kumar, A. (2015). User satisfaction regarding quality of library services of A.C. Joshi Library, Panjab University, Chandigarh. DESIDOC Journal of Library and Information Technology, 35(1), 54-60.

Mukhtar, U., Anwar, S., Ahmed, U., \& Baloch, M. A. (2015). Factors Effecting the Service Quality of Public and Private Sector Universities Comparatively: an Empirical Investigation. Journal of Arts, 6(3), 132-145.

Nawarathne, I. M., \& Singh, A. P. (2013). Users' Satisfaction of the Academic Library Services in Sri Lanka. Pearl/ : A Journal of Library and Information Science, 7(2), 103.

Onditi, E. O., \& Wechuli, T. W. (2017). Service Quality and Student Satisfaction in Higher Education Institutions: A Review of Literature. International Journal of Scientific and Research Publications, 7(7), 328-335.

Pereira, M. A. C., \& Silva, M. T. DA. (2003). A key question for higher education: Who are the customers. Annual Conference (pp. 4-7)

Santini, F. de O., Ladeira, W. J., Sampaio, C. H., \& da Silva Costa, G. (2017). Student satisfaction in higher education: a metaanalytic study. Journal of Marketing for Higher Education, 27(1), 1-18.

Sario, M. L. P. (2015). Students' Satisfaction Survey on Pnu - N1 Services. Journal of Arts, Science \& Commerce, VI(3), 7788. 
Sarsale, M. S., \& Caday, S. G. (2020). Exploring quality of student services of a philippine state university satellite campus using servqual and service improvement matrix. Malaysian Online Journal of Educational Management, 8(2), 59-71.

Schertzer, C. B., \& Schertzer, S. M. B. (2004). Student satisfaction and retention: A conceptual model. Journal of Marketing for Higher Education, 14(1), 79-91.

Sharma, J., Kaur, G., \& Kaur, S. (2018). Total Quality Management in Teacher Education Institutions. International Journal for Research in Applied Science and Engineering Technology, 6(4), 2354-2357.

Silva, F., \& Fernandes, P. O. (2012). Empirical Study on the Student Satisfaction in Higher Education: ImportanceSatisfaction Analysis. WASET Journal, 6(9), 1075-1080.

Sojkin, B., Bartkowiak, P., \& Skuza, A. (2012). Determinants of higher education choices and student satisfaction: The case of Poland. Higher Education, 63(5), 565581.

Stang, J. (2015). Ethics in Action: Conducting Ethical Research Involving Human Subjects: A Primer. Journal of the Academy of Nutrition and Dietetics,
115(12), 2019-2022.

Sukhdeep Kaur. (2016). Student Support Services in Higher Education: A Student Perspective. International Journal of Indian Psychology, 3(3).

Taber, K. S. (2018). The Use of Cronbach's Alpha When Developing and Reporting Research Instruments in Science Education. Research in Science Education, 48(6), 1273-1296.

Temizer, L., \& Turkyilmaz, A. (2012). Implementation of Student Satisfaction Index Model in Higher Education Institutions. Procedia - Social and Behavioral Sciences, 46, 3802-3806.

Thompson, A. (2014). Fostering Growth and Development of Recovering Students in Higher Education Through Servant Leadership. Peabody Journal of Education, 89(2), 244-257.

Waugh, R. F. (2002). Academic staff perceptions of administrative quality at universities. Journal of Educational Administration, 40(2), 172-188.

Weerasinghe, I. M. S., \& Fernando, R. L. S. (2018). Critical factors affecting students' satisfaction with higher education in Sri Lanka. Quality Assurance in Education, 26(1), 115130. 